sediment xenoliths ranging in size from a few millimetres to $20 \mathrm{~cm}$. These occur together with up to $2 \mathrm{~cm}$ long prismatic phenocrysts of orthopyroxene and small globules of iron. The globules range in size from $0.5-10 \mathrm{~mm}$ and are rimmed with less than $1 \mathrm{~mm}$ of the iron mineral troilite. The smaller globules are spherical, probably due to surface tension in the molten stage, whereas larger ones are elongate or amoeboid. Except for the iron globules, which may show a very weak tendency for gravitational concentration, phenocrysts and xenoliths occur unevenly distributed in a matrix of a fine-grained, globular-textured rock similar to that found at Asuk (Pedersen, 1973).

The different types of 'andesitic' core rocks can be distinguished in the field by their joint patterns and by differences in their phenocryst and xenolith content. However, they are all characterised by a distinct, tar-like smell from fresh fracture surfaces.

An additional intrusion occurs to the west. Large amounts of 'andesitic' loose blocks in solifluction debris along a fracture zone on the plateau south of Hammers Dal indicate that the intrusion occurs along a NNW-SSE trending zone for about $7 \mathrm{~km}$.

Near the settlement Diskofjord a dyke of weakly contaminated basalt was found, probably corresponding to that found by K. J. V. Steenstrup and known from specimens in the collections of the Mineralogical Museum, Copenhagen. At the west dyke contact a body $30 \mathrm{~cm}$ across of massive pyrrhotite intergrown with coarse dendritic black glassy material containing fine needles of cohenite was found. Near the east contact a subvertical zone with branching iron bodies was observed.

*Added in proof. Now inverted to the low temperature polymorph, troilite.

\title{
References
}

Pedersen, A. K. 1973: Report on field work along the north coast of Disko, 1971. Rapp. Gronlands geol. Unders. 53, 19-27.

Pedersen, A. K. in press: New mapping in north-western Disko, 1972. Rapp. Gronlands geol. Unders. 69, 25-32.

Mineralogisk Museum, $\emptyset$ ster Voldgade 5-7, 1350 Copenhagen $K$.

\section{Field mapping of the pre-3760 m.y. old supracrustal rocks of the Isua area, southern West Greenland}

\section{Jan H. Allaart}

The first of a two-summer mapping programme on the Isua supracrustal rocks was undertaken as part of a larger mapping project aimed at the completion of the 1:500 000 map sheet Søndre Strømfjord - Frederikshåb Isblink.

The Isua supracrustal belt with its major occurrence of banded ironstone was dis- 
covered and mapped by geologists of Kryolitselskabet $\emptyset$ resund A/S (Keto, 1970). A $\mathrm{Pb}-\mathrm{Pb}$ whole rock isochron age of $3760 \pm 70 \mathrm{~m}$.y. for the banded ironstone has been obtained by Moorbath et al. (1973). Bridgwater \& McGregor (1974) spent 14 days in the area in 1973.

The belt consists of an incomplete oval-shaped arc around a dome-shaped area of gneiss. The southern part trends east-west and occurs on both sides of the lake Imarssuaq. East of the lake the belt is narrow and less than $1 \mathrm{~km}$ wide. Further east it curves to the north-east and increases in width to about $4 \mathrm{~km}$ at the margin of the Inland Ice. West of the lake the belt curves to the north and eventually to the north-east. At its north-west side the belt is cut out by an important ENE-WSW trending fault.

In general the supracrustal rocks are remarkably little affected by mobilisation phenomena of the surrounding gneisses. Only locally do thin veins of gneiss penetrate the schists and amphibolites. Close to the contacts thicker light coloured pegmatite sills and lenses occur in the dark coloured supracrustal rocks. Therefore great attention was paid to mapping the main units of the belt in the hope of confirming the suggestion of Keto (1970) and Bridgwater \& McGregor (1974) that the belt had a bilateral symmetry and represented a synform. The results were inconclusive, any evidence of the possible synclinal disposition of the more or less vertical standing supracrustal belt being obscured by the intense deformation (see James, this report).

The following succession was mapped from the south-eastern outer margin to the north-western, inner margin of the belt $10 \mathrm{~km}$ and more to the north-east of lake Imarssuaq, where the belt is thickest. (See also Keto, 1970).

(1) Amphibolites with occasional thin layers of garnet-biotite schist and magnetitebearing banded quartzite.

(2) Siliceous and carbonate-bearing biotite-muscovite schists which in places are regularly banded with layers of concentrations of strongly attenuated fragments. Most of the fragments consist of potassium-rich, acid metavolcanic rocks, although pebbles of gneiss have also been reported (Bridgwater \& McGregor, 1974; James, this report).

(3) In the succeeding unit, which might constitute the core of a major original synform, a varying quantity of amphibolites occurs together with a considerable amount of carbonate-bearing (e.g. siderite) rocks, garnet-biotite schists, garnet-staurolite-biotite schists, biotite-hornblende schists and quartzites which in many places are magnetitebearing and finely banded. This unit also contains the major ironstone occurrence (Keto, 1970) most of which is under the Inland Ice. The individual bands of magnetite and quartz are much thicker than in the minor banded ironstones elsewhere in the supracrustal belt. In addition to the banded magnetite-quartz ironstones there are several small occurrences of banded magnetite-siderite ironstone. These are always associated with conspicuously green garnet-chlorite schists. In this unit there is also an important conglomerate horizon with stretched quartzite pebbles, in a matrix of garnetbiotite-muscovite schist. Along the western side of this unit a rather broad zone of garnet-rich schists occurs; it has not been observed along the south-eastern side of the unit. 
(4) Siliceous and carbonate-bearing schists with horizons of stretched acid metavolcanics. These schists may constitute a repetition of the second unit, but this is impossible to prove.

The bilateral symmetry of the belt is very imperfect. Units 1 and 2 can be followed along almost the whole course of the oval-shaped supracrustal belt. However, in the westernmost part, where the belt trends north-south, the units curve around towards the south-west. The relations are not yet understood and have still to be mapped out. Unit 3 which attains maximum width at the margin of the Inland Ice thins out towards the south-west, whilst amphiobolitic rocks become more and more predominant. Layers of carbonate-bearing rocks are less common, but thin horizons of banded ironstone, garnet-biotite schist and biotite-hornblende schist are frequent. Some of the banded ironstones can be followed for several kilometres. Unit 4 is sheared out halfway between the Inland Ice and the lake Imarssuaq. Thus along the lake the succession is even more incomplete than close to the Inland Ice.

West of the lake Imarssuaq, where the southern continuation of the belt curves from east-west to north-south, the third, possible core unit of the original synform is again much thicker than just east of the lake. It is continuously exposed until it is cut off by an ENE-WSW trending fault to the north-west. The unit here consists mainly of amphibolitic rock, but horizons of garnet-mica schist and banded quartzite with some layers of banded ironstone are common. Very often the quartzites are interbanded with carbonate layers; the latter also occur independently in the amphibolites.

In the western half of the belt, west of Imarssuaq, a thick body of hornblendechlorite-plagioclase schist showing garbenschiefer texture occurs within unit 3 . It is a rather basic rock and is probably intrusive in origin. East of this body, at the inner side of the belt, fine-grained amphibolites occur with some bands of banded quartzite, banded ironstone, garnet schists and concordant ultrabasic intrusions.

East of Imarssuaq the hornblende-chlorite-plagioclase schist with garbenschiefer texture occurs along the Inland Ice where it has a very irregular form with clearly discordant contacts mainly intruding unit 3.

Conformable zones of talc-actinolite-chlorite schist in which relics of dunite have been preserved in many places are rather common throughout the supracrustal belt. In the east-west trending southern part of the belt at both sides of Imarssuaq, the ultrabasic zones are mainly concentrated along the contacts between units 1 and 2, and 2 and 3. Many quartzitic horizons in the immediate neighbourhood of the ultrabasic bodies contain the chrome-bearing mica fuchsite. At several localities greenish, chert-like quartzites with microscopic fuchsite occur and could well be used as semiprecious stones.

In several places fold closures of mesoscopic, close folds were observed. They were too small to reveal anything of the possible original synclinal disposition of the supracrustal belt, and no major fold closures were seen. At least two successive phases of deformation have been recognised, both producing isoclinal folds (see James, this report).

Two sets of metadolerite dykes cut across the supracrustal rocks and the gneisses. One set is radial and the other tangential to the oval-shaped structure of the belt. 
The dykes of the radial set preserve primary fine-grained margins and coarse-grained centres ard are undeformed. Some of the tangential dykes are completely undeformed, some have foliated contacts and undeformed centres while others have a well developed schistosity throughout. Isoclinally folded horizons of homogeneous amphibolite which may be of intrusive origin also occur. It thus seems clear that dykes of the tangential set belong to a number of different generations. Probably some were syntectonic in age.

Although study of thin sections has shown that most of the supracrustal rocks underwent amphibolite facies, followed by retrograde greenschist facies metamorphism, it is possible that in some parts of the belt the metamorphic grade never reached amphibolite facies. Work on this problem is in progress.

The kind assistance and hospitality of Kryolitselskabet Øresund A/S during the field work is gratefully acknowledged. Prof. P. E. Cloud Jr., Univ. of California, Santa Barbara, is also thanked for helicopter assistance at the end of the season.

\section{References}

Bridgwater, D. \& McGregor, V. R. M. 1974: Field work on the very early Precambrian rocks of the Isua area, southern West Greenland. Rapp. Grønlands geol. Unders. 65, 49-54. Keto, K. 1970: Isua, a major iron discovery in Greenland. Kryolitselskabet Øresund A/S, $13 \mathrm{pp}$.

Moorbath, S., O'Nions, R. K. \& Pankhurst, R. J. 1973: An early Archaean age for the Isua iron-formation. Nature phys Sci. 245, 138-139.

\section{Deformation of the Isua supracrustal belt, southern West Greenland}

\section{Patrick R. James}

A reconnaissance investigation of the deformation of the Isua supracrustal belt was carried out at the end of the field season. Helicopter transport was kindly provided by Prof. P. E. Cloud Jr. (Univ. of California, Santa Barbara) who was visiting the area to search for possible early life forms in the rocks of the Isua supracrustal belt.

The structures contained within the supracrustal rocks and surrounding gneisses can be described with reference to two major deformation episodes, here designated $D_{1}$ and $D_{2}$.

The first phase of deformation $D_{1}$ produced an intense $L S$ tectonic fabric $\left(S_{1}, L_{1}\right)$ in both the supracrustals and in some of the surrounding gneisses. This fabric most commonly parallels the original bedding in the sediments and the original layering in the gneissic rocks. The type of fabric varies, depending upon the lithology of the host rock, with a lineated slaty cleavage developing in the finer grained metasediments and metavolcanic rocks whilst the gneisses developed mylonitic foliation and fluxion banding 